\title{
6
}

\section{The role of curriculum: advancing capabilities and functionings for a public good education}

\author{
Melanie Walker
}

\begin{abstract}
discussion of the capabilities approach is provided by Hall (chapter two) with reference to the purpose of higher education and by Bozalek and Leibowitz (chapter five) with reference to the social justice in the institution as a whole. This chapter considers how curriculum should focus on human development (Haq, 2003) and, more specifically, form graduate functionings and capabilities - that is, support diverse students' opportunities to be and to do in ways they have reason to value (Sen, 1999; Nussbaum, 2011) as a matter of social justice in higher education. A focus on curriculum re-inserts but also problematises the 'knowledge' bit in the knowledge economy and knowledge society. Knowledge is important both in dominant human capital approaches and also for human capabilities, but in rather different ways. On the one hand, there is the development of knowledge - often thought of as skills - for employability and financial gain; on the other, there is the development of knowledge for cultivating critical and creative intellectual capacities for meaningful lives. These differences are explored in the chapter, and the argument made for human capabilities as the superior approach for curriculum.
\end{abstract}

\section{Knowledge and curriculum}

Knowledge is central to the higher education project but for particular reasons. Curriculum foregrounds knowledge, the criteria for its selection and inclusion and how it is mediated pedagogically and acquired by learners. 
Curriculum determines the selection of what counts as valid knowledge (Bernstein, 1975) and, more expansively, the range of formal learning opportunities available to students. Importantly, statements about what should be included in a curriculum exemplify what things powerful groups in a society think students should learn and thereby promote particular student identities. Knowledge carried by a curriculum logically has significant effects and projects forward into anticipating and preparing for the future (Young, 2010). Thus a curriculum encapsulates value judgements about what knowledge is considered important; for example the ethical dimensions of biotechnology advances, or the equal importance of exposure of all students to arts and science knowledge, or which literatures are studied. But a curriculum further indicates what attitudes and values students are expected to emerge with in respect of the knowledge and skills they have acquired, for example how to use scientific knowledge or historical understanding. Curriculum is thus a statement of intent; though there may be practical gaps between what is intended by those constructing the curriculum, implementing it in action and what is actually learned by the students who experience the curriculum.

Moreover, debates, conflict and disagreements about curriculum are at root cultural, social and political (Karseth, 2006), turning on knowledge - what is worthwhile, what to put in, what to leave out, how to structure a programme, to whom it is distributed, who decides and so on - and directly affecting learning opportunities. Curriculum has wider consequences for how knowledge, carried by individual graduates, is distributed in society and has an instrumental 'role in making a particular form of society' (Young, 2010:21). Barnett and Coate (2005) have pointed to the surprising absence of curriculum studies in higher education. Although a growing body of work is emerging (for example, Bovill et al, 2011), not all of it focuses on research. There has been a major overhaul of the undergraduate curriculum at the Universities of Aberdeen, Hong Kong, Melbourne and Macquarie, to take just four examples, that aimed to change practices and align graduate outcomes with the demands of the 21st century. However, what is envisaged in each case is not necessarily something different from dominant neoliberal policy; it may well even aim at a closer alignment with marketised discourses and practices, and may include concerns to maintain elite rankings in global measurement tables and shares of the lucrative international student market.

From a research point of view, where curriculum in higher education is studied it tends to focus on the contestations between a discipline-based model and a vocation or professional model and how these are being challenged by a market-led discourse which emphasises flexibility, mobility and 
employability (Karseth, 2006; Young, 2010) and/or policy convergences, such as Bologna in Europe (Karseth, 2006). A version of this debate for South Africa is explored by Ensor (2004), who identifies two key curriculum discourses driving change: a disciplinary discourse and what she describes as a credit accumulation and transfer discourse located in market-led pressures of globalisation up against local reform initiatives. Similarly, in their comparative study of Indonesia, Nicaragua and Vietnam, Mason et al (2001) argue that credits and curriculum measures in higher education are linked to market-driven economic systems. While disciplinary discourses still emerge as having power, this is being eroded by interdisciplinary approaches on the one hand and market-led public policy and discourses of flexibility and employability on the other (Mason et al, 2001). As a consequence instrumental aims are overtaking the intrinsic goods of knowledge, curriculum and learning.

However, study of a different kind is also emerging, one which attempts to 'bring knowledge back in' (Young, 2010; Muller, 2012) alongside the 'possible selves' (Clegg, 2011) that curriculum enables. To take just a few examples, Barnett (2009) has written recently about curriculum and the links between knowledge and student being and becoming, while Nussbaum's (1997) study of liberal arts education in the USA addresses curricular reform and the core values of liberal education in considerable depth. Clegg (2011) connects curriculum, context independent, socially powerful knowledge, social class and widening access. She raises the problem of reducing knowledge to social positions and thereby ironically constraining the identities produced for disadvantaged individuals and groups.

Meanwhile, an especially robust study of curriculum in South Africa (see Shay 2011 for cited papers) is linked in part to the country's policy concern with 'epistemological transformation' (Shay, 2011) as well as to an older tradition influenced by its apartheid past. University researchers were concerned with how curriculum knowledge entrenches or transforms power relations, and who gets to limit or enable socially powerful identities. The best of the current work explores the fine-grained working out of knowledge and pedagogical relations, and raises tough questions about well-meaning curriculum reform which seeks to make knowledge accessible but may have outcomes quite contrary to those intended. Particular difficulties are posed for students from weaker academic backgrounds (see Case, 2011).

Notwithstanding such challenges, a focus on curriculum change offers the crucial possibility of making more sustainable shifts than might come from the characteristic focus on teaching and learning, where so much rests on 
individual teachers. In curriculum reform, we find a powerful combination of curriculum structures, which are institutionally embedded and persist over time, and individual efforts aligned with these and evaluated against them. Thus attention to curriculum as a university-wide project holds considerable - and sustainable - transformative potential, and the possibility of inclusively mobilising a university community about worthwhile education from a human development perspective.

\section{Human capital or human capabilities}

Since there is no space to explore the range of noted curriculum debates, here I focus on the 'space' in which these contestations around knowledge and identity formation can be worked out. I draw on principles shaped by human development (Haq, 2003) and capabilities (Sen, 1999; 2009; Nussbaum, 2010; 2011) to try and connect knowledge, identities and valued 'functioning capabilities' with normative models of curriculum reform and understandings of what it means to be human.

It is worth restating that universities play a special role in society through their core activities of advancing knowledge and scholarship and educating students and professionals. Habermas (1989), for example, argues that universities constitute a space for the 'lifeworld' to flourish, where the moralpolitical liabilities of the age can be addressed against the colonising effects of the 'system' (money and power) which distorts communicative rationality. Looking internationally, the Talloires Declaration (2005) affirms the civic and social roles of universities; there are hundreds of signatories from universities across the globe. Similarly, the research, policy and practice of the Global University Network for Innovation (GUNI) (eg 2008) describe the new dynamics of social responsibility for universities. These are hopeful positions.

Yet in contemporary times higher education is most commonly presented globally as the key arena for turning a country into a competitive and dynamic knowledge-based economy, capable of combining economic growth with greater social cohesion and the public good. These are arguably incommensurable goods; for universities to reconcile economic growth with human flourishing will be more difficult in practice. Moreover, where policy is strongly oriented only to human capital and economic growth outcomes, as is the case in England, any reconciliation seems often unattainable. Martha Nussbaum (2010) describes this as the insatiable thirst for economic growth and human capital outcomes driving education policy around the world. 
Human capital as the dominant driver of higher education policy involves the idea that a university education is an instrumental means to something else - human capital. It is assumed that individuals invest rationally in themselves to improve their own economic returns through career advancement or better earnings (Keeley, 2007), an assumption that underlies the view that time spent in university education is supposed to pay off in the future. Credentials rather than critical knowledge are what counts. Better-educated countries also tend to be wealthier, or become so, which further reinforces the economic link between the economy and education (Keeley, 2007). As long as economic growth is proceeding, the problem of an uneven distribution of human capital and uneven labour market opportunities for people with equal amounts of human capital - women, migrants, the disabled, and so on - is left unaddressed. Seen as an end in itself, economic development is prioritised over social inclusion, which, if mentioned, is 'thin'. It is assumed that other improvements will follow human capital expansion so that in the first instance economic growth is traded off against quality of life. Growth is then put forward as the dominant normative framework for development; other activities like higher education are justified in so far as they foster growth. Human capital remains philosophically and normatively wedded to seeing people first and foremost as engines of economic productivity, so students are educated to become economic producers, consumer-citizens and entrepreneurial selves. In human capital terms this is the underpinning philosophy of what it means to be human.

Yet the links between economic growth and human development are not automatic: even where there is high economic growth, valuable lives can prove elusive. Even in most developed countries (OECD, 2008) increased economic growth has not eradicated inequalities, nor has human capital generated jobs and opportunities. In countries like Spain unemployment among the under25s has now reached 52 per cent and there seems little point in studying further (Tremlett, 2012). Brown et al (2010) point to the dysfunctionality of the human capital model as higher education increasingly fails to deliver opportunities to students in the West and knowledge jobs migrate to lower wages in the East. Moreover, as Wendy Brown (2011:23) argues, transformations or 'conversions' in the direction of academic human capital in universities 'interpellate the subject only as speck of human capital, making incoherent the idea of an engaged citizen, and educated public, or education for public life'.

Knowledge in a human capital model has become the currency of the powerful. Science and technology may also contribute to the problems societies face today, for example in the manufacture of chemical and biological 
weapons (Vessuri, 2008). Knowledge has become another tradable commodity and higher education a service industry included in the scope of the World Trade Organisation (WTO) (Vessuri, 2008). The emphasis on human capital and status further shapes and reshapes knowledge. As academic career advancement increasingly turns on investing most of one's human capital in research activity (Brown, 2011), instead of transferring knowledge through dedicated undergraduate teaching, research ironically becomes less relevant to teaching, the public good and making a better world.

It is not that human capital is bad as a goal for universities: fair economic opportunities, a productive business environment and reducing human insecurity are central to human well-being. Integration into economic life matters if people are to participate fully in income generation and secure fair and remunerative employment. But income alone cannot capture the full range of plural contributions to a state of well-being in a person's life: work, life, community and relationships also count. We need a richer set of goals and aims for university education and a curriculum which imagines ethically inclusive and humanly rich goals for development and pays close attention to the practical effects of higher education on the lives of human beings.

Sen's (1999) capability approach and its development by Nussbaum (2010; 2011) could provide a more comprehensive perspective and attractive normative approach. By acknowledging human capital but also subsuming it within an approach which values human well-being, it sees each person as an end in themselves and not as the means to some other end. Sen (2009) rejects the view that improved lives can only follow from economic growth: a range of valued human ends ensure that being a better producer is not the only evaluative end for human lives. The key purpose of development, he argues, is human development. While income and economy would still matter, the purpose of educational development should be to enlarge all worthwhile human choices.

University education can contribute to what Sen (1999) calls 'capabilities': the freedoms to choose and develop valuable beings and doings - what he calls 'functionings' or achievements - which enable us to live in ways that are meaningful, productive and rewarding both to society and to ourselves as individuals. Nussbaum (2012:128) explains capability as the modern form of what Aristotle termed dunamis, meaning, 'very generally, that condition in virtue of which one is able to do something'. For Nussbaum, capabilities are external opportunities - the capability of voting, for example - and internal capacities - such as making political choices. For both Sen and Nussbaum, 
society is evaluated not according to how much income and wealth it provides people, but to the extent that it has made them capable of various important activities - mobility, for example, or 'access to political life' (Nussbaum, 2012:252). Capabilities are thus 'substantial opportunities for choice' (Nussbaum, 2012:404). We are enjoined to ask: what are people actually able to do and be? What opportunities and genuine choices do they have to attend a university, to be healthy, to be creative, and so on? Capabilities are these real and actual freedoms that give people the power to do and be what they value being and doing.

As noted earlier, a capabilities approach to curriculum should be embedded within human development theory, along with its associated development dimensions as explained by Gasper (2002):

- empowerment and participation in the expansion of capabilities

equity in opportunities to form capabilities

- sustainability of opportunities to freely exercise one's capabilities

community membership - belonging

- human security.

Crucially, human development is concerned that all should have the opportunity and means to live long, creative and fulfilling lives so these dimensions operationalise this inclusive and public good interest in educational aims and decisions. One needs to ask how capabilities are distributed in and through higher education, to whom and why, and who is left out? Being human would then involve a capacious life of human flourishing, dignity and agency. The goal of education would be to provide the curriculum and pedagogical conditions in which graduates' capabilities could develop, even though how such capabilities are exercised would then depend on the choices individuals make. Nussbaum (2010:88) writes that 'once the stage is fully set, the choice is up to them'. The two questions for universities that follow from this are as follows: can curriculum and pedagogy be operationalised to enable the formation of dignified relationships and social cohesion and will this allow public good values to inform each person's post-university decisions? What one is choosing between is important, and curriculum might form the appropriate commitments and values that are enriching and fulfilling for both the individual and society. Moreover, if democracy requires conviction it is then the role of education and curriculum to help people arrive at those they deem worthwhile (Tawney, 1966). 


\section{Curriculum and capabilities}

For Sen (Dreze and Sen, 1995), the kind of education that forms human capabilities is rich and 'thick'; it has both an instrumental and an intrinsic value that is multi-dimensional as well as transformative potential. Crucially, education affects the development and expansion of other capabilities so that an education capability expands other important human freedoms. Sen (2009) offers some indirect curriculum and pedagogical guidance when he ascribes a central role to our powers of 'public reasoning' as a moral and political imperative. The advancement of justice depends on democracy deepening democracy depends on discussion and collective reasoning that injects more information and knowledge, diverse perspectives and plural voices into debates. This process of public reasoning facilitates through open debate continuous scrutiny and assessment about how a society (or university) and its members are doing, and includes debate about values and principles and the curriculum.

Critical enquiry and discussion practices in universities should produce justice or at least reduce injustice, for example by developing graduates with critical knowledge, critical self-reflection and the capacity to act in the world. This learning process - what Habermas (1989) calls 'argumentation' - is connected to healthy democracies and is what universities should do. Clearly, if universities claim to develop critical and communicative reasoning, they ought to play a key role in forming public-reasoning capabilities. Curriculum and pedagogies of implementation are then central to how such directions might be realised. Open, critical and scholarly discussion in universities is essential to this education project; in the sphere of education it is key. 'It constitutes a human world, and it is itself educative ... Discussion is the principal way in which humanity is cultivated' (Morrow, 2009:10) and therefore has a central role in human life.

Further guidance is offered from Sen's (2009) emphasis that capability is a kind of power and a central concept in human obligation. Agency through curriculum must then include 'other-regarding' goals and obligations to use one's power on behalf of other human beings. By reason of our shared humanity we are enjoined to bring about the changes that would enhance human development. Sen emphasises that if someone has the power to make a change that they can see will reduce injustice in the world, there is a strong social argument for doing so.

Unlike Sen, Nussbaum is in favour of a list of ten central universal capabilities (Nussbaum, 2010) and education is implicit and explicit in the development 
of these. Although highly contested (see Crocker, 1995 and Gasper, 2002 for this debate), her list adds content to the abstract notion of capabilities which can be formed through education: for example to be knowledgeable; to use one's knowledge in worthwhile ways; to be interculturally aware and sensitive, and so on. Nussbaum is thus educationally helpful - even if one does not agree with her priorities. For example, her capability of 'senses, imagination and thought' is defined in this rich way:

Being able to use the senses to imagine, think and reason - and to do these things in a 'truly human way', a way informed and cultivated by an adequate education, including but by no means limited to literacy and basic mathematical and scientific training. Being able to use imagination and thought in connection with experiencing and producing self-expressing works and events of one's own choice, religious, literary, musical and so forth. Being able to use one's mind in ways protected by guarantees of freedom of expression with respect to both political and artistic speech, and freedom of religious exercise. Being able to search for the ultimate meaning of life in one's own way. Being able to have pleasurable experiences and to avoid non-necessary pain. (2010:78-9)

More specifically, Nussbaum (1997) has identified three education capabilities for both quality in education and the formation of democratic citizens. Her first is a focus on the examined life, which involves the capacity for selfawareness and autonomy developed through searching ('thick') critical thinking in which one asks: 'what do I want to stand for and for what am I personally accountable?' Such questions are exposed to searching scrutiny, evidence and argument. Students learn to deal with differences among themselves and their disagreements; they take responsibility for their own reasoning and debate ideas with others in an atmosphere of mutual respect for reason. The second capability is being able to see oneself as a world citizen. Nussbaum's global citizens are bound not only to a local community but interconnected to distant human beings by ties of equal dignity and genuine curiosity about the lives of others. This requires us to think about the glaring inequalities in the world and the defects in models of global development based on GDP and incomes. In this way students acquire the understanding that increases the likelihood of solving common problems in the world, since these are everyone's problems and not just those of one group or country. The third capability is that of 'narrative imagination', by which Nussbaum means the ability to understand intelligently how the world is experienced by someone different from oneself, their emotions, desires and vulnerability. It requires empathy and a genuine and humble attempt to understand the lives of others. 
More recently, in arguing for the arts and humanities in higher education, Nussbaum (2010) has proposed a number of specific capabilities worth fostering:

- develop students' capacity to see the world from the viewpoint of other people, particularly those whom their society tends to portray as lesser, as 'mere objects'

teach attitudes towards human weakness and helplessness that suggest that weakness is not shameful

develop the capacity for genuine concern for others, both near and distant

undermine the tendency to shrink from minorities of various kinds in disgust

teach real and true things about other groups, so as to counter stereotypes

- promote accountability by treating each [student] as a responsible agent

vigorously promote critical thinking, the skill and courage it requires to raise a dissenting voice. (see p45-6)

How curriculum does this is then the educational development question.

It is important to note that the territories of human development, capabilities and functioning are multi-dimensional - the development of one supports the development of the others so aims, pedagogies and outcomes would need to be aligned with each of them separately. Aligned with human development and Nussbaum's and Sen's capabilities and guidance on education, such a model to guide curriculum discussion and practice might include the following (see Table 6.1 opposite).

\section{A curriculum example}

In a recent research project exploring the contributions of professional education in universities to reduce poverty in South Africa (Walker et al, 2010), curriculum emerged as both a recurring theme and a key element in appropriate 'public good' educational arrangements across fields of law, engineering, public health, theology and social work. The work curriculum can do was exemplified by the social work education provided at one South African university, included in the project case study sites. In this department, social work lecturers face the considerable challenge of educating diverse young people who may not have been exposed to the hardships many South Africans face. Students need critical exposure to a curriculum which enables 


\begin{tabular}{|c|c|c|c|c|}
\hline $\begin{array}{l}\text { Curriculum } \\
\text { values }\end{array}$ & $\begin{array}{l}\text { Indicative } \\
\text { capabilities }\end{array}$ & Knowledge & Pedagogies & $\begin{array}{l}\text { Identities and } \\
\text { functionings }\end{array}$ \\
\hline $\begin{array}{l}\text { empowerment, } \\
\text { participation } \\
\text { equity } \\
\text { sustainability } \\
\text { community } \\
\text { human security }\end{array}$ & $\begin{array}{l}\text { knowledge, } \\
\text { intellectual } \\
\text { development \& } \\
\text { critical } \\
\text { reasoning } \\
\text { respect } \\
\text { imagination \& } \\
\text { empathy } \\
\text { obligations to } \\
\text { others less } \\
\text { advantaged } \\
\text { cosmopolitan } \\
\text { citizens }\end{array}$ & $\begin{array}{l}\text { interdisciplinary } \\
\text { approaches, } \\
\text { ethics, global } \\
\text { processes } \\
\text { scrutiny of } \\
\text { inequalities } \\
\text { human } \\
\text { interconnection } \\
\& \text { natural } \\
\text { environment }\end{array}$ & $\begin{array}{l}\text { Socratic } \\
\text { methods } \\
\text { discussion and } \\
\text { dialogue critical } \\
\text { thinking } \\
\text { reflexive } \\
\text { practices } \\
\text { inclusive \& } \\
\text { intercultural } \\
\text { methods }\end{array}$ & $\begin{array}{l}\text { disciplined and } \\
\text { independent } \\
\text { thinker having } \\
\text { multiple } \\
\text { perspectives on } \\
\text { the world open- } \\
\text { minded } \\
\text { aware of moral } \\
\text { and ethical } \\
\text { debates and } \\
\text { questions } \\
\text { courage to } \\
\text { decide what } \\
\text { one stands for } \\
\text { and for what } \\
\text { one is } \\
\text { accountable } \\
\text { respect for the } \\
\text { natural } \\
\text { environment } \\
\text { decent humble } \\
\text { curious and } \\
\text { respectful } \\
\text { towards all } \\
\text { others }\end{array}$ \\
\hline
\end{tabular}

\section{Table 6.1: Curriculum, human development and capabilities}

their understanding of the structural factors in society that cause and perpetuate poverty and inequality. Thus one lecturer explained that if students ...

don't understand root causes they're going to be working on symptoms and perpetuating the inequalities and inequities of the past, the imbalances, the critical development challenges, they're going to be part of the problem and not part of the solution. They're going to be putting on band aid strips as opposed to understanding where the leverage needs to come in order to make shifts in power and in access to resources and access to opportunities, etc. So they will never be able to help people increase their capabilities and capacities if they are unable to see what the blocks are to that actually happening. 
She argued that for students to play a transformative role in their own professional lives, they need to have values and principles based on social justice. Lecturers therefore aim to develop in students an understanding of social justice, as embodied in the South African Constitution, so that it comes to underpin their professional work. They felt students should acquire a knowledge and understanding of historical inequities, as well as policies and programmes which aim to transform society so that people's rights would be realised. Social work graduates need to understand global trends which affect South African society because

it's critically important to understand the forces that are at play from the level of global trends, globalisation of the economy, the impact of trans-national companies, the impact of everything that's happening in the economic sector on the country and right down to the level of individual people who are poor and unemployed and why they are poor and unemployed and in the situation that they are in'.

Thus this lecturer wanted students to be able to understand the links between micro, meso and macro contexts and between the local and global. In this way - through curriculum - the social work department sought to educate particular kinds of graduate professionals, oriented to critical contributions to society and the public good.

The approach captures both the concern with epistemological access to critical social theory (noted earlier) and so on, and the concern with the work curriculum can do to transform unjust power relations and form identities of 'public-good' professionals, equipped with the knowledge and values to work for wide and deep social change in South Africa.

\section{Concluding thoughts}

Acquiring critical knowledge matters in higher education both intrinsically and instrumentally for social change. As Sen puts it: 'public reasoning is quite central to democratic politics in general and to the pursuit of social justice in particular' (2009:44). Grounded in human development, capabilities and functioning achievements, curriculum could form rich human beings so that teaching and learning and graduate formation is then one site where we can work to advance justice or reduce injustice in the world (Sen, 2009). The capability approach could contribute to curriculum, teaching and learning for rich human understanding and connections. Students would then learn not only a curriculum of knowledge and skills, but the difference between simply having knowledge and skills on one hand and, on the other, having the 
commitment and values to use these to the benefit of others. Additional theories may be required for a fine-grained look at how curriculum works to enable development, and the capabilities approach is sufficiently flexible to accommodate additional theories where these are well aligned with the core normative concerns for freedoms and well-being and agency achievements.

In a world of growing inequalities, it ought not to be beyond the imaginative reach and responsiveness of universities, and ourselves as the people who work in them, to harness the wealth, creativity and power of humanity in the 21st century to create a better world than the one we currently have. The alternative may well be what Rabindranath Tagore, quoted by Nussbaum in Not for Profit (2010:1), warns of as a 'shrinkage of the soul'.

In the end it matters for sustainable lives and future persons that we in universities ask ourselves: What could public universities be doing and what should they be trying to achieve? What curriculum would convert the resources of public education into actual benefits for students and society?

\section{References}

Barnett, R (2009) Knowing and becoming in the higher education curriculum. Studies in Higher Education 34(4) 429-40

Barnett, R and Coate K (2005) Engaging the Curriculum in Higher Education. Maidenhead: Open University Press

Bernstein, B (1975) Class, Code and Control: Volume 3 - Towards a Theory of Educational Transmissions (second edition). London: Routledge and Kegan Paul

Bovill, C, Bulley, C and Morss, K (2011) Engaging and empowering first-year students through curriculum design: perspectives from the literature. Teaching in Higher Education 16(2) 197-209

Brown, P, Lauder, H and Ashton, D (2010) The Global Auction: The broken promises of education, jobs and reward. New York: Oxford University Press

Brown, W (2011) The end of educated democracy. Representations 116 19-41

Case, J (2011) Knowledge matters: interrogating the curriculum debate in engineering using the sociology of knowledge. Journal of Education 51 1-19

Clegg, S (2011) Cultural capital and agency: connecting critique and curriculum in higher education. British Journal of Sociology of Education 32 (1) 93-108

Crocker, D (1995) Functioning and capability the foundation of Sen and Nussbaum's development ethic Part II. In M Nussbaum and J Glover (eds) Women, Culture and Development. Oxford: Oxford University Press

Dreze, J and Sen, A (1995) India: economic development and social opportunity. In The Amartya Sen and Jean Dreze Omnibus. New Delhi: Oxford University Press

Ensor, P (2004) Contesting discourses in higher education curriculum restructuring in South Africa. Higher Education 48 339-59

Gasper, D (2002) Is Sen's capability approach an adequate basis for considering human development? Review of Political Economy 14(4) 435-61

GUNI (2008) Higher Education in the World. Hampshire: Palgrave MacMillan 
HIGHER EDUCATION FOR THE PUBLIC GOOD: VIEWS FROM THE SOUTH

Habermas, J (1989) The idea of the university: learning processes. In J Habermas, trans. S Weber Nicholson The New Conservatism: cultural criticism and the historians' debate. Cambridge: Polity Press

Haq UI M (2003) The human development paradigm. In S Fukuda-Parr and A K Shiva Kumar (eds) Readings in Human Development. Oxford: Oxford University Press

Karseth, B (2006) Curriculum restructuring in higher education after the Bologna Process: a new pedagogic regime. Revista Espanloa de Educacion Comparada 12 255-84

Keeley, B (2007) Human Capital. Paris: OECD

Mason, C, Arnove, R and Sutton, M (2001) Credits, curriculum, and control in higher education: cross-national perspectives. Higher Education 42 107-37

Morrow, W (2009) Bounds of Democracy: epistemological access in higher education. Pretoria: HSRC Press

Muller, J (2012) Forms of knowledge and curriculum coherence. In $\mathrm{H}$ Lauder et al (eds) Educating for the Knowledge Economy? London and New York: Routledge

Nussbaum, M (1997) Cultivating Humanity. A classical defence of reform in liberal education. Cambridge, MA: Harvard University Press

Nussbaum, M (2010) Not for Profit. Princeton: Princeton University Press

Nussbaum, M (2011) Creating Capabilities. Cambridge, MA: The Belknap Press

Nussbaum, M (2012) Philosophical Interventions. New York: Oxford University Press

OECD (2008) Growing Unequal? Income distribution and poverty in OECD countries. Paris: OECD

Sen, A (1999) Development as Freedom. Oxford: Oxford University Press

Sen, A (2009) The Idea of Justice. London: Allen Lane

Shay, S (2011) Curriculum formation: a case study from history. Studies in Higher Education 36(3) 315-30

Talloires Declaration (2005) The Talloires Network. http:www.tufts,edu/talloiresnetwork/ (Accessed November 2009)

Tawney, R (1966) The Radical Tradition. Harmondsworth: Penguin Books

Tremlett, G. The Guardian Weekly (2012) Spain's crash is no laughing matter 11 May 2012, 5

Young, M (2010) Bringing Knowledge Back In. London and New York: Routledge

Vessuri (2008) The role of research in higher education: Implications and challenges for an active contribution to human and social development. In GUNI (eds). Higher Education in the World 3. Higher Education: new challenges and emerging roles for human and social development. London: Palgrave

Walker, M, McLean, M. Dison, A and Vaughan, R (2010) Higher education and poverty reduction: the formation of public good professionals in universities. http://www.nottingham.ac.uk/Education ResearchProjects/DevelopmentDiscourses.index.aspx. (Accessed April 2011) 